\title{
Resilience: A “Psychosocial” Competency and Its Role in the Pathways of University Students in Intercultural Research (Pre and Post-COVID19)
}

\author{
Miriam Aparicio \\ Lead Researcher, CONICET (National Council for \\ Scientific and Technical Research, National University of \\ Cuyo, Parque General San Martin, Mendoza, Argentina
}

\section{Abstract}

Rapid changes to the workplace, even more so after the pandemic, demand education in competencies different from strictly disciplinary competencies, competencies which allow the individual to deal with emergencies and which imply a renewal of professional and institutional identity, favoring restructuring, employability and professionalization focused on future needs. In this paper, the focus is on what the author describes as a "psychosocial competency" in light of her theory, or Resilience. Like resilience, this theory, the Three Dimensional Spiral of Sense, involves three interacting and selfsustained levels: micro (individual), meso (organizational) and macro (national). We present two studies in which the impact of Resilience was observed: a) on academic achievement for delayed students, associated with institutions that do little to promote resilience and b) its importance in the shared representations of university students with respect to the competencies necessary for facing new challenges in the workplace. This group was taking part in a bilateral exchange program in France. COVID-19 suddenly placed them in an emergency situation, which demanded flexibility and the ability to adapt (stranded, without financial or health resources and lacking psychosocial support). Both research studies refer to the Quality of university education as regards Achievement, Professionalization, Identity and Employability. Both reveal deficiencies in the education system in terms of coping with crises. The methodologies, respectively, were quantitative (bivariate and multivariate level) and qualitative (techniques: interview and hierarchical evocation). The results of both studies show: a) the relevant role of Resilience with respect to Achievement; b) the lack of development in this regard. Finally, with a view towards transfer and intervention, a proposal is made to create and/or improve resilience and other psychosocial competencies by means of agreed-upon psychosocial support programs. ${ }^{1}$

1 PICTO Project 2016-0008. BID Loan. Argentina. 
Keywords: university, internationalization, identities, professionalization, employability, resilience

\section{Introduction}

Our own research, beginning in the 1990s, addresses factors linked with University Quality as it relates to the productive and scientific context. Currently, Quality and Evaluation of Quality have become the focus of the political-educational agenda. Interest was given to the analysis of factors that impact (both positively and negatively) the Achievement of university students (graduates, delayed students and dropouts) as well as, indirectly, the Quality of educational institutions and national innovation. Studies covered more than 20 incoming classes in 18 study programs at two national universities (Argentina). They were carried out from a sui generis systemic perspective that involves several psychosocial micro-theories and three levels - micro, meso and macro - observed self-sustainably (Aparicio 2005; 2012; 2015 a and b). The models included base variables as well as pedagogicalinstitutional, psychosocial, organizational and structural variables. We also worked with other populations (government workers, healthcare workers, teachers, students at various levels, judges, scientists, etc.) ${ }^{1}$.

This research had already demonstrated the importance of competencies - which two decades ago I called "social" and "collective" - both for Achievement and for coping with adversity. Socializing instances were deemed essential and socializing education required as these competencies are not innate, the context influences their "coconstruction" together with the individual, feeding each other. The interactive perspective came together in a theory which I have called, in its latest version, The Three Dimensional Spiral of Sense (2015a, b). Twenty-five years have passed and in the last three years, the OECD has shown the impact of these competencies for the ten highest ranked countries as regards learning (OECD, 2017a and b; 2018 a, b, c, d; Agacisti, 2018). Nevertheless, the findings of a first study with delayed university students and a recent study with students participating in international exchanges continue to show that some of these competencies, which I now call "psychosocial" competencies, were not sufficiently developed; or at least students were not made aware of their importance for dealing with adversity. COVID-19 has suddenly presented us a difficult scenario: these competencies are developed at the middle and long term, yet emergencies do not wait. The results invite us to reflect upon and rethink the "new normal". On the one hand, this will force us to reinvent ourselves, turning to creativity, entrepreneurship and critical thinking, and to rethink our life

\footnotetext{
1 The findings were presented in more than 200 publications and paved the way to a second doctorate at the Sorbonne (France) and to two opportunities to direct research in the European Union (HDR, field of Education and Organizational and Workplace Psychology).
} 
projects. On the other hand, it will teach us to resist and to face adversity with flexibility and without losing our balance, even when we live in "pathogenic" contexts.

Additionally, at the academic/professional level, this new world for which we are not prepared will have an impact on dropout rates ${ }^{1}$, particularly for the most vulnerable groups. These rates were already high in Argentina and Latin America (Aparicio, $1995 ; 2014)^{2}$. It is predicted that dropout rates will influence equity and equality of opportunities (Aparicio, 1973/1983) and quality of global life. Both students and professors alike will be affected by the elimination of jobs and demands for new professional profiles due to the abrupt advance of digitalization. This will be added to already high rates of dissatisfaction and burnout (Freudenberger, 1974; Aparicio offers synthesis based on empirical research: 2009 a and b; 2015 a, b and c). Faced with a structural crisis, the global stage will require new competencies co-constructed by individuals, the organizations of which they are a part and public policy.

\section{Theoretical Framework}

\subsection{The notion of Resilience and its evolution: from a static concept to a dynamic and procedural concept}

Resilience may be defined as the individual's capacity to react to and cope with adversities due to an adaptation process and in spite of risks and the adversities themselves. As we see it, all of these elements are essential as regards success and failure. We should clearly state that the ability to deal with pressure and lead a healthy life in an unhealthy environment implies social and intrapsychic processes in which institutions and primary socializing instances play a fundamental role (Puerta de Klinkert, 2002, Cirulnik, 2001, 2002, 2004). Resilience is, then, a personal and institutional construction, it is not innate. It is formed within a context. For this reason, it was included in our theoretical model and analyzed from our sui generis systemic approach. It is the context in which the individual is inserted, the factors that enhance or diminish the possibility of overcoming obstacles. In view of the "relative" failure of students who are delayed in their studies, two questions arise: Is a low level of resilience involved? Does the university community, with its dominant system of beliefs and values, influence the probability of being successful? Without understanding the situation based on empirical data, it is quite difficult to make changes at the level of intervention.

The concept of resilience is not new. It was first used in metallurgy and engineering to describe the ability that certain materials have of restoring themselves to their

\footnotetext{
${ }^{1}$ In Argentina, dropout rates are around 70\%; in other countries of the region, the average dropout rate is close to 55\%: Guatemala (82\%), Uruguay (72\%), Bolivia (73\%), Brazil (59\%), Chile (54\%), Costa Rica (54\%) and Mexico (53\%). In countries like Spain, the US and Austria, the dropout rate is between 30 and $50 \%$.

${ }^{2}$ A synthesis of English and Spanish literature on dropout can be found in Aparicio, 2020 (in press in Germany). Another synthesis can be found in UNESCO/IESALC (Higher Education Institute for Latin America and the Caribbean) (2020, post COVID-19) and Webinaire F. Pedró, June 2, 2020
} 
original shape after being subjected to distorting pressure (Royal Spanish Academy, Salvat Encyclopedia of Science and Technology, 1964). Dyer et al. (1996) define as it the flexible or elastic quality of a substance.

In positive psychology, the notion of resilience appears in the 1960s, and even more so in the 1970s and 1980s ${ }^{1}$. At the beginning, in early psychiatric literature, Anthony (1974) made no distinction between Resilience and Resistance, confusing "invulnerable" and "invincible" with resilient. Later, the longitudinal studies of Werner \& Smith (1982), carried out with multiracial groups (exposed to risks in Hawaii), were decisive for establishing the differences between the two concepts ${ }^{2}$.

Briefly, the concepts of invulnerability and invincibility - referring to "fixed" or "static" qualities - lost ground in favor of resilience, which is a dynamic notion that implies a process. Moreover, the authors discover protecting factors: self-esteem, Independence, connections, initiative and critical thinking - factors considered pillars of resilience. They highlight the difference between physics and psychology. In physics, resilience refers to the ability to return to a state prior to changes applied by extreme forces. In psychology, on the other hand, the concept is broader as it does not involve returning to a previous state. It implies reconstruction of the psychic apparatus, with more efficient organization which is capable of facing the future after the impact of trauma (Lorenzo, 2010).

The dynamic perspective has as its "founding father" Michael Rutter (1985, 1991 and 1992; Rutter, MacDonald, Le Couteur, Harrington, Bolton \& Bailey, 1991). From a psychological perspective, the author conceives of protecting factors not as being opposite of risk factors but rather the two form a dynamic that allows strengthening of the individual when faced with situations of adversity, respecting at all times personal characteristics.

Kotliarenco, Cáceres \& Fontecilla (1997) describe the evolution of the concept of resilience in three stages. The first implies acceptance of a "positive adaptation" that "invulnerable" or "resistant" individuals have, that is, those who are capable of "resisting" adversity (Henderson \& Milstein, 2003). As such, invulnerability is the first notion. It refers to people who seem to be strong and who do not yield to the pressures of stress and adversity.

Later, however, this concept was considered incorrect due to the fact that resistance to stress is relative. It is not stable over time, varying according to an individual's stage

\footnotetext{
${ }^{1}$ In Spanish, the concept is introduced later, between 2001 and 2005 (Aparicio, 2007 a; 2009 b; Grotberg, 2008).

2 Dyer \& Minton McGuinness explain the longitudinal study of Werner \& Smith (1982), carried out with a group of 698 children born in 1955 in Hawaii. Several families lived in poverty and their members had different mental and physical abilities. Researchers combined biological, social and psychological factors considered predicative of vulnerability and invulnerability when faced with serious problems. They observed that the "invulnerable" youth that had suffered shorter separations from their mothers during their first year of life were active and socially receptive and reached development milestones.
} 
of development and with circumstances. Moreover, the roots of resilience come both from the environment and the individual's own constitution (Rutter, 1985; Klotiarenco et al. 1997).

For her part, Edith Grotberg (2003) defines Resilience as the interaction of factors at three levels: social support (I have), abilities (I can) and internal strength (Here I am and I have). The important element is interaction, with people always playing an active role in events and contexts. Barnard (1999) and Manciaux (2003) share the same perspective: resilience is a dynamic process.

The second stage consists of replacing the concept of invulnerability with that of resilience. The difference resides in the fact that resilience can be formed/consolidated while invulnerability is considered an intrinsic characteristic (Rutter, 1991).

\subsection{Resilience as a "psychosocial" competency from a systemic perspective or a "sustained" co-construction between individuals and contexts}

Aparicio offers another vision in light of her theory. She analyzes resilience as a "psychosocial competency" within sustained macro-meso-micro-macro interplay. In its conception, we may not understand an individual outside of his immediate and mediate contexts, gaining feedback from a particular dialectic that implies spiral movement, with effects that may be both positive and negative (2005; $2007 \mathrm{a}$ and b; $2009 \mathrm{a}$ and b, $2015 \mathrm{a}$ and b). This is very different from the hyperfunctionalist and deterministic spiral, as "each situation" deserves to be analyzed in its own time, in its own space and according to its own circumstances in dynamic interplay or selfsustained giving and taking of "individuals and their contexts". From this notion comes the name of the author's theory (cit. supra, 2005, 2012, 2015a and b). Her approach breaks with the genetic determinism of an individual, which presupposes an epistemological focus on the human being, influenced but not determined by his cultural context. It recognizes the potential individuals have for development. Nevertheless, this development may or may not be achieved, depending on the existence or lack of responsibility on the part of socializing instances (family, peers, school, university), on the influence that the social and cultural contexts have and, fundamentally, on the richness of connections. Such influences, interacting with an individual's strengths, will allow him to adapt to adversity and successfully overcomes risks and adversity.

\subsection{Other concepts related to resilience}

- Ability: defined as social ability or success in one activity (Becoña, 2006). This competency implies effectiveness of action (execution in the field). Masten 
(1999; 2001) argues that "competency" and "resilience" are two closely related constructions that form part of a more general adaptive construction. ${ }^{1}$

- Positive adaptation: Adapting means adjusting, that is to say it implies internal changes and changes in types of relationships (Lorenzo, 2010). But there is only resilient accommodation when there is positive accommodation.

- Strength: There is a difference between strength and resilience. Resilience takes into account adaptive and constructive behavior in the struggle to be successful in a given situation. Therefore, an individual who commits no social crime could be considered strong but not resilient (Novella, 2002).

- Coping: Lazarus \& Folkman (1980) define coping as the cognitive and behavioral efforts made to improve specific external and internal demands that are evaluated beyond an individual's resources ${ }^{2}$.

The aspects which make Resilience stand out are: i) resilience always requires adaptive behavior from all sectors; ii) to have resilience, there must be an adverse or stressful situation. With coping, on the other hand, responses may or may not be adapted to daily events; iii) resilience requires effective adjustment strategies, that is efforts to maintain internal or external balance through activities related to thought and action. Individuals must adapt to stressful events and to do so must assess situations through the use of adjustment strategies (Manciaux et al, 2003).

As regards the topic at hand, and particularly as it relates to the Research 2 group, which is currently facing the COVID-19 emergency and will later face the postpandemic era, we can see that successful adjustment will require adaptive behavior in the realm of education, "organizations that learn", the health sector and social development in the face of enormous increases of poverty. It will be necessary to adapt to the structural changes that are already beginning to be seen (millions of jobs lost, among other aspects).

In this regard, we believe it is important to analyze the value given to resilience by university students and the degree to which it is present in their social representations as a competency to be reinforced for overcoming adversity. This is essential because these representations, which must be reviewed collectively, are followed by new models of action, concrete practice and action (Moscovici, 1961; Argyris, 1982). In other words, if resilience is not sufficiently valued, both at the individual level and at the institutional level, it will be more difficult to deal with the

\footnotetext{
${ }^{1}$ Luthar (1993) highlights the fact that there is a difference between the two concepts: competency does not imply risk. Nevertheless, Perrenoud (2000) defines competency as the ability to mobilize a set of cognitive resources (knowledge, abilities, information, etc.) to face a family of situations pertinently and effectively. It means being able to transfer what was learned, to have autonomy in one's learning and to resolve problems. These personal/professional situations may imply risks.

2 Establishing the differences goes beyond our objective here. In Research 1, both variables were measured with different techniques.
} 
consequences of COVID-19. The findings that link Resilience to Achievement point in this direction (at the international level and from my own research).

\section{Contributions of resilience at the university level}

Traditionally, educational institutions have been concerned with detecting errors instead of identifying strengths. From our perspective, it is most important to concentrate on acquiring and developing abilities, skills and strengths, as opposed to focusing on weaknesses. And it is here that resilience can make enormous contributions. Findings from research carried out in countries at the top of the educational rankings prove this (Rutter, 1987; PISA / OECD, ops. cits).

Briefly, education plays a central role in developing resilience in children, adolescents and academics, helping them to deal with both academic and workplace difficulties (Melillo, Suarez \& Rodríguez, 2004 and Coronado-Hijón, 2017). Pulgar Suaso (2010) affirms that a resilient student is committed and responsible, has more selfconfidence and greater control over his future, tends to feel included and participates more in social networks. These characteristics impact success. Likewise, Goleman (1996) warns that emphasis placed on cognitive-technological models, as opposed to social skills in higher education, leads to the emergence of fear, insecurities, instability and lack of self-control. On the other hand, an institutional context which promotes resilience among its students and ad intra (among its teaching and administrative staff) acts to prevent crises. Multiple findings support this idea. However, Henderson \& Milstein (2003), who have worked in formal educational environments, maintain that this has not been well-studied at educational institutions, and much less in higher education.

In the same vein, it is important both for individuals and for institutions themselves to incorporate programs that promote leadership, motivation, study habits, participation and responsibility. These were precisely the factors which were addressed in our research. Finally, the Delors Report (UNESCO, 1996) identified four pillars of education policy for quality: knowledge, know-how, good manners and learning to be. The first two correspond to traditional models, attempting to measure to justify results. The latter two, within which programs to consolidate resilience are inscribed, are becoming more and more important in contexts of globalization and emergency as they seek to promote social integration and the construction of citizenship.

\section{Objectives and questions/hypotheses of our research}

\subsection{Objectives}

\subsubsection{General Objectives:}

Research 1 (DELAY): to understand he factors (core, psychosocial, structural, pedagogical and institutional) associated with success at university and in particular the importance of resilience. 
Research 2 (IAM - INTERNATIONAL ACADEMIC MOBILITY): to observe the importance university students participating in academic exchanges give to resilience, both for their integration into a new culture and for facing the demands of a new working world.

\subsubsection{Specific Objectives:}

Research 1 (DELAY): a) to determine the sociocultural and psychosocial factors which significantly influence delay in studies; b) to Identify the at-risk population and; c) to provide elements to the authorities of each institution with which to implement changes which will in turn contribute to achievement.

Research 2 (IAM): To observe the role that this group attributes to Resilience as it relates to the demands of the working world, with the rapid adaptation that it requires and the degree of adjustment to these demands/competencies that educational institutions must take into account.

\subsection{Hypotheses}

Research 1 (DELAY): Higher degrees of Resilience (RESIL) have a positive impact on University Achievement (UP) and on the chances of labor insertion.

Research 2 (IAM): in the social representations of students and/or professionals who participate in international academic exchanges, Resilience will be an important factor for adaptation: a) at the moment of entering into a different macro and organizational context and; b) when facing the future world of work and its demands.

\section{Methodology}

We used both quantitative and qualitative methodology.

\subsection{Guiding questions}

\section{* DELAY and IAM Group}

1- Are there differences in representations of resilience between university students studying in Argentina and those who have chosen to participate in exchange programs in Europe? These exchanges would allow us to think that the IAM group has a certain ability to adapt.

2- What strength does Resilience have as a factor associated with academic and professional achievement in both groups? These questions seem naïve but the answers given have left us perplexed.

\section{* IAM Group Only:}

3- What role do university students interviewed in Paris give to Resilience as it relates to the demands of the new world of work?

4- Do their social representations (evident in their responses) show the importance that Resilience will have when they are faced with the changes and innovation that 
the new world of work will demand post-COVID-19? (Gaglio, 2011; Alter, 1999; Alkrich, Latour \& Callon, 2006)

5- Do they value being prepared for adjustments that will mean, more than ever, supporting and strengthening connections or, on the contrary, does its role appear diluted, revealing little awareness of the need for such preparedness?

We must point out that in this paper (IAM Group), we will not go into an analysis of all of the questions proposed in Research 2.

Keeping in mind our objective, to observe the importance Resilience has as regards the current demands of the world of work in addition to the essential aspects which define it, we have attempted to respond to the above questions.

The findings are presented in two instances, result of the application of the hierarchical evocation technique. Firstly, we observe what importance the IAM group gives to Resilience. Secondly, we observe the importance given to five aspects related to this competency: i) connections; ii) the ability to adapt to change; iii) its role as regards rapid adjustments; iv) problem-solving abilities and; v) flexibility.

Briefly, their responses reveal the awareness they have of the importance of this variable, an importance which will only increase due to the effects of the pandemic and the need to overcome adversity in the world of work. Likewise, their responses allow us to observe which competencies they believe must be strengthened (among professors and students) in light of abrupt changes and the need to quickly adjust.

Lastly, it is important to point out that we will analyze both the responses as well as the "silences", as "silences" as such do not exist. They speak for themselves of a lack of awareness, deficiency, lack of involvement and disinterest.

\subsection{Sample groups}

\section{Research 1 (DELAY):}

The sample group consisted of individuals at six Schools, including Philosophy and Literature (Educational Sciences), Economic Science (Accounting and Management), Political Science (Social Communication), Law, Medicine and Engineering (Civil, Industrial and Petroleum Engineering), at the National University of Cuyo (1985 2004). They were interviewed at home. These individuals had enrolled at the university starting in 1985 and reenrolled in 2004 but are not currently attending courses; they are ghost students. Out of 1880 individuals identified in institutional listings, the number of students interviewed (students we were able to locate) was $\mathrm{N}=229$.

\section{Research 2 (IAM):}

The sample group consisted of university students participating in academic or business exchange programs starting in 2018 in Paris (Cité internationale). We worked with several classes of students (2002-2003, 2013-2014 and 2018-2019) 
(descriptive/percentage quantitative level) and at the qualitative level (2018-2019) we worked face to face with volunteers $(20 \%$ of the total). This paper will deal with the qualitative level.

\subsection{Techniques}

\section{Research 1 (DELAY):}

-We used a semi-structured interview and specific tests to measure the different psychosocial variables related to achievement (UP): Strategies to "overcome" difficulties (Frydenberg \& Lewis, 1996), Attributional Styles (Seligman, 1991) and Resilience (Henderson \& Milstein, 2003). In this work, we deal with the importance of Resilience for overcoming difficulties within university institutions.

-As regards Resilience, Henderson and Milstein's questionnaire consists of three scales: Student (RESIALUM), Staff (RESIPERS), both the administration and teachers, and Institutional (RESIFACU); its six sub-scales can be regrouped into two subdimensions. The aspects evaluated include: I. Reducing risk: 1 . Enhancing pro-social bonds; 2 . Defining clear and firm limits (Creating and implementing coherent school policies and procedures and explaining expectations in terms of behavior. Stating written rules and transmitting them clearly; 3. Teaching competences for life (cooperation, critical thinking, communication competencies, problem solving skills, healthy stress management); and II. Constructing Resilience: 1 . Providing affection and support; 2. Defining and transmitting high and realistic expectations (avoiding the notion of development plafond); 3. Providing opportunities for significant participation (granting both students and those in charge of making decisions the chance to determine goals with the help of others).

As regards University Achievement (UP), in a broad sense, it comprises the following categories: a) Achievement: finishing studies (obtaining the degree); b) Delay: finishing studies in a longer period of time than the officially pre-determined one; and c) Failure: dropout.

Strictly speaking, performance was understood considering the following indicators (UNCuyo Statistics Department):

- Number of years studying (2005 - COHORT)

- Number of years needed for the study program (ANIPLAN)

- Subjects failed (MATPLAN-REUSSI)

- Total number of subjects in the curriculum (MATPLAN)

- Number of failures (APLAZOS)

- Subjects passed (MATPLAN) 


$$
U P=\left\{\frac{1}{\left\{\left[\frac{(2005-C O H O R T)}{A N I P L A N}\right]+\left[\frac{\text { MATNOAPR }}{\text { MATPLAN }}\right]+\left[\frac{\text { APLAZOS }}{\text { APROBADA }}\right]\right\}}\right\}
$$

\section{Research 2 (IAM):}

Interviews were conducted, as well as a semi-structured interview.

Here we have decided to approach the matter in two instances and only as it relates to the variable/dimension "World of Work".

\section{Instance 1:}

The hierarchical evocation technique was used (Abric, 2001). The objective was to understand how the "World of Work" appeared in their shared representations (central or peripheral), as well as the predominance of positive or negative aspects.

Four categories resulted from the combination of the frequency with which words were used and the importance given to them: 1) Educational Dimension; 2) Organizational, Sociopolitical and Structural Dimension; 3) Economic Dimension; and 4) Relational/Motivational Dimension (Resilience located here). According to the aforementioned combinations, these four categories are located in different quadrants: P2, P3, P4 and P1.

In the P2 quadrant (nucleus of the representation) are the most frequent and most important categories; in the P3 quadrant, those most frequent but least important; in the P4 quadrant, those which are overall the least important; and finally, in the P1 quadrant (low frequency and high importance), appear the so-called elements of contrast or innovators that show group differences. Through the use of this technique, we were able to understand the most notable convergences and divergences.

\section{Figure 1. Quadrants (Hierarchical evocation technique) ${ }^{1}$.}

\begin{tabular}{|l|l|}
\hline P1 (-+) & P2 (++) \\
\hline P4 (- -) & P3 (+-) \\
\hline
\end{tabular}

\section{Instance 2:}

Taking into account our focus here, Resilience, we sought to observe what relevance this variable was given in the face of rapid adaptation which the workplace is

\footnotetext{
${ }^{1}$ Note: Frequency of word appearance is located on the $\mathrm{x}$-axis, while Importance given the word is located on the y-axis.
} 
currently demanding. We therefore proceeded to count how many times the word Resilience and four related words were mentioned.

Lastly, we must also point out that the following qualitative dimensions were observed as they relate to the issue at hand, though they are not the object of our analysis here. They are included in Figure 2.

1- Which competencies do companies value according to students of the hard sciences?

2- Which competencies do companies value according to students of the soft sciences?

3- Which competencies do universities value according to students of the hard sciences?

4- Which competencies do universities value according to students of the soft sciences?

5- What should be a priority to change in the development of competencies for professors?

6- What should be a priority to change in students' education in the place of workplace transformations?

These students' representations are of particular interest as this group theoretically received superior education and passed selection processes to continue their studies in Europe.

\section{Results (IV)}

\section{Research 1 (DELAY)}

Results show the role of Resilience in the Extension of Studies (UP).

The Resilience factor, as previously stated, was measured using three scales: Student (RESIALUM), Staff (RESIPERS), both administrative and teaching, and Institutional (RESIFACU). For all three scales, the average is focused on category three, which indicates that Resilience training is at the "initial" stage. This means that, in general terms, in all Schools, institutional evaluation as a means of modeling Resilience in students, in staff and in the institution as an organization is quite low. On the other hand, each institution has its own profile, since some appear as to encourage Resilience among students, staff and/or the institution itself (Aparicio, 2009a

There should be resilience resource areas (see Schools/Courses in Study I of our research) favoring this competency, that is, instances favoring: a) the creation of supportive social networks; b) the consolidation of a transcendental meaning of life; c) the development of skills to build solid, respectful and rewarding relationships in order to obey rules and accept limits in a conscientious manner; d) the ability to solve problems through analysis and reflection; and e) the development of self-esteem based on a realistic viewpoint of one's own potential and limitations.

Below is analysis of results showing the variables which influence achievement. 
Bivariate Analysis: As regards factors for "overcoming obstacles" in our Resilience and Coping model, the results show that the most significant Resilience Scales are the Pro-social Bond (RESIVINC), Clear Limits (RESILI) and High Expectations (RESIEXPE). More precisely, when the Pro-social Bond increases, University Performance (UP) decreases. On the contrary, when there are Clear Limits and High Expectations, UP increases.

We stress, then, the positive effect of expectations in relation to learning limits, something that is lacking nowadays. On the other hand, there is the very high pro-social bond, which leads to dropout. At the level of demands, experience in different Schools shows that as demands increase, so does performance (lower rate of delay in studies).

Multivariate Analysis: Let us focus for a moment on the University Achievement (UP) model and analyze which variables can predict achievement. Among the Psychosocial Variables, Resilience is precisely the most influential. Two sub-scales are associated with UP: bonds and opportunities offered to individuals (RESIVINC and RESIOPOR). The former contributes negatively; that is, the more students are devoted to social life, the more their levels of achievement drop. The latter contributes positively. In other words, the more opportunities for progress, the higher the UP.

RESIVINC: Probability is lower than 5\% (0.0328). Coefficient is -0.003520 , which reveals a negative relationship with UP. In other words, when these bonds are exaggerated and sociability is considerable, studying becomes less important and studies become delayed.

RESIOPOR: Probability is lower than 5\% (0.00057), which indicates a higher association in the multivariate model than RESIVINC. Coefficient is 0.004104; that is, there exists a positive relationship with UP. When there are opportunities for development, academic performance improves and delaying studies decreases.

\section{Research 2 (IAM)}

\section{Instance 1: Analysis of central and peripheral categories of the "World of Work" dimension}

The "Motivational - Relational" Dimension is located in the nucleus or heart of the representation (P2). It is, therefore, the most important as the majority of responses are concentrated here: $\mathrm{F}=43.5 \%$; $\mathrm{I}=44 \%$. In other words, almost $50 \%$ of the responses are found in this category.

Practically all of the rest are located in the "Organizational/Sociopolitical/Structural" category: $\mathrm{F}=28.3 \%$; $\mathrm{I}=28 \%{ }^{1}$.

\footnotetext{
1 Values are given for the four constructed categories: 1 ) Education ( $\mathrm{F}=3.3 \% ; \mathrm{I}=3 \%) ; 2$ )

Organizational/Sociopolitical/Structural (F=28.3\%; I=28\%; Economic: (F=11\%; I=1\%); 4)

Relational/Motivational ( $\mathrm{F}=43.5 \%$; $\mathrm{I}=44 \%$ ).
} 
What stands out is that in the first category, where Resilience should be located, the word did not appear even once ${ }^{1}$. This goes against our hypothesis.

Table 1: Category «Item 38.1 World of Work» (IAM)

\begin{tabular}{|l|l|l|l|}
\hline \multicolumn{2}{|l|}{ Subjects } & 23 \\
\hline \multirow{2}{*}{ Sub-categories } & 4 & $100 \%$ \\
\hline \multirow{2}{*}{ Frecuency } & Maximun & 92 & $25 \%$ \\
\cline { 2 - 4 } & Hight & 23,00 & $100 \%$ \\
\hline \multirow{2}{*}{ Importance } & Maximun & 230 & $19 \%$ \\
\cline { 2 - 4 } & Hight & 45 & \multicolumn{2}{|l|}{} \\
\hline
\end{tabular}

\begin{tabular}{|c|c|c|c|c|}
\hline Importance & $<<$ Education $>>$ & $\begin{array}{l}<<\text { Organizational- } \\
\text { Socio-polítical and } \\
\text { Estructural }>>\end{array}$ & $<<$ Economic $>>$ & $\begin{array}{l}<<\text { Relational- } \\
\text { Motivational }>>\end{array}$ \\
\hline 1 & $0,0 \%$ & $6,5 \%$ & $0,0 \%$ & $13,0 \%$ \\
\hline 2 & $1,1 \%$ & $6,5 \%$ & $1,1 \%$ & $9,8 \%$ \\
\hline 3 & $1,1 \%$ & $10,9 \%$ & $0,0 \%$ & $8,7 \%$ \\
\hline 4 & $1,1 \%$ & $5,4 \%$ & $0,0 \%$ & $12,0 \%$ \\
\hline \multirow{3}{*}{ Frecuency } & 3 & 27 & 1 & 40 \\
\hline & $3,3 \%$ & $29,3 \%$ & $1,1 \%$ & $43,5 \%$ \\
\hline & Low & Hight & Low & Hight \\
\hline \multirow{3}{*}{ Importance } & 6 & 67 & 3 & 102 \\
\hline & $3 \%$ & $29 \%$ & $1 \%$ & $44 \%$ \\
\hline & Low & Hight & Low & Hight \\
\hline
\end{tabular}

1 The Table and Graph (qualitative) are referred to in Aparicio, 2017-2020. PICTO. 


\section{Graph 1a. Categories «Item 38.1. World of Work » (IAM)}

Category <Item 38.1 World of work>

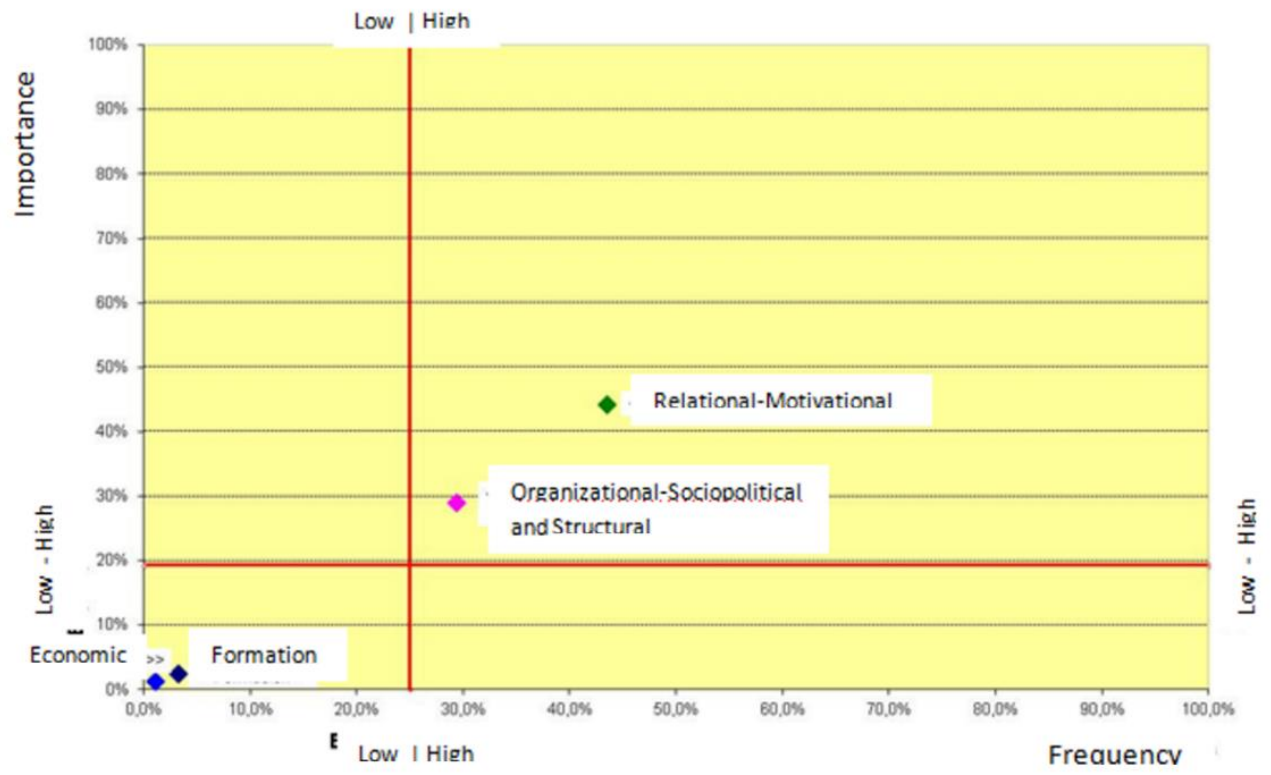

Graph 1b. Categories «Item 38.1. World of Work » (IAM)

Category <Item 38.1 World of work >

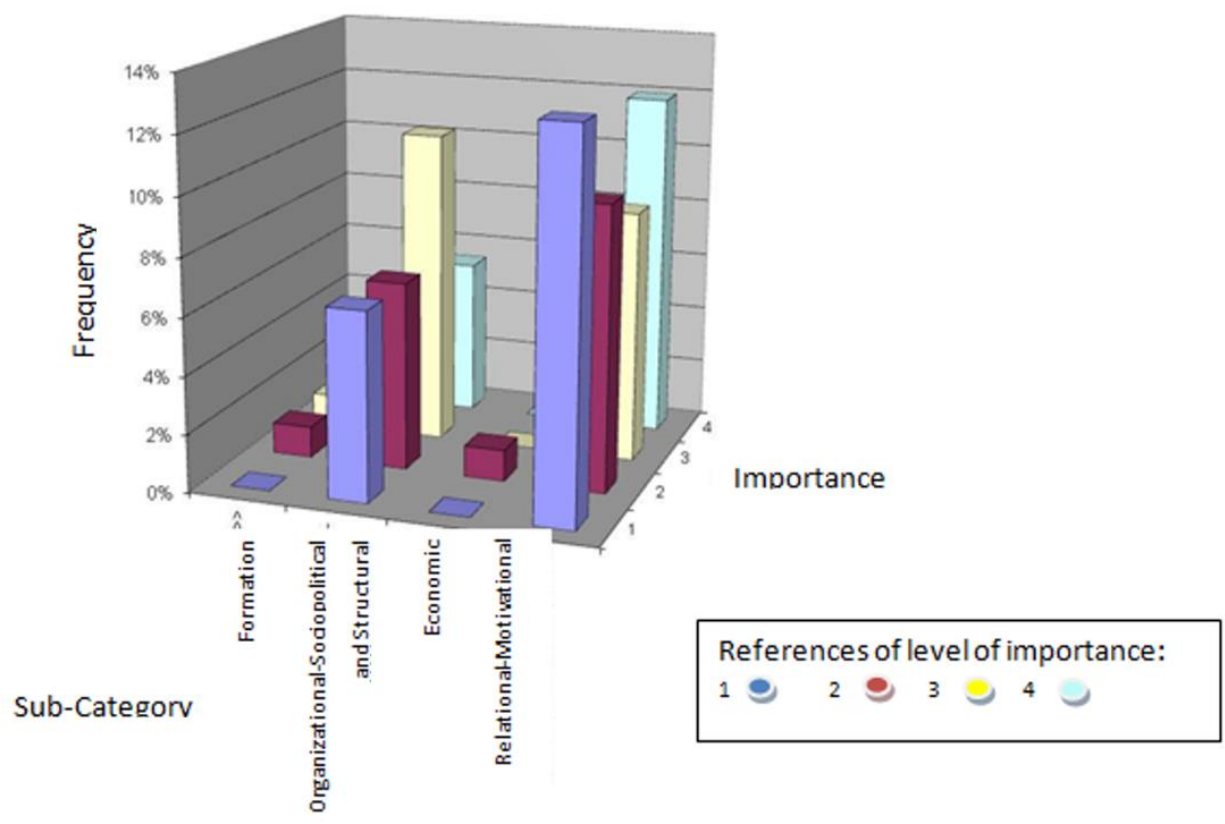


In the "Motivational - Relational" category, we observe that the majority of the responses see the world of work as something positive. Respondents describe it as: "factor of fulfillment" and "identity" (these were the most-used words), but also as: "interesting", "dynamic", "visibility factor", "satisfaction", "socialization", "a place to apply what you've learned", "essential", "construction", "challenge", "something that gives personal and social value", "respect for others", "a reason for happiness", etc.

On the other hand, in the "Organizational-SocioPolitical-Structural" category, the majority of words evoked were negative: "negative", "imposed", "exploiter" (repeated frequently), "destructive", "unequal", "precarious", "cage”, "slavery", "racist", "ungrateful", "little respect for minorities", "meritocracy", "bad compensation for another's work", "unjust" (repeated frequently), "with shortcomings in evaluation and in work conditions" ("many hours daily", "little time for rest", "little vacation time", "unequal treatment"), "competitive", "closed", "leading to low quality of life", etc. This reflects certain nonconformity with the functioning of workplace organizations and of macro policies adopted in the field.

Two respondents finally pointed out that it presents "many changes" which would imply that it will require adjustment, the ability to adapt and, indirectly, Resilience.

Focusing on the issue at hand, the word "resilience" was never mentioned as an ability nor, according to the author's conception, as a "psychosocial competency" important to carrying out one's work daily under current conditions, conditions which have already had negative effects at the level of health, such as increases in burnout, low levels of satisfaction, decreases in wellbeing and falling expectations, among others.

\section{Instance 2: Number of times words referring to Resilience appeared}

These words included: Adjustment/Change, Adaptation, Resolve, Connections and Flexibility 1.

Once again, the word Resilience never appeared. In the "World of Work" Dimension, only $2 \%$ of respondents mentioned the word adjustment/change. The other words listed are not the focus of this analysis, however, the percentages of mentions of words that could refer to Resilience are extremely low 2 .

\section{Table 2: Frequency of appearance of words related to Resilience}

Competencies valued

Words Analyzed

\footnotetext{
1 It is important to note that after studying what was said by each respondent, we observed something which has not been mentioned by other authors applying the technique and which we have observed repeatedly. In effect, tendencies in individuals' responses (words mentioned) are observed. That is, those who have negative representations tend to make this evident through the majority of their words and the same happens with those having positive representations.

2 The item number from the semi-structured interview is maintained.
} 


\begin{tabular}{|c|c|c|c|c|c|c|c|}
\hline & $\begin{array}{l}\text { Resilien } \\
\text { ce }\end{array}$ & $\begin{array}{l}\text { Adjus } \\
\text { t/ } \\
\text { Chan } \\
\text { ge }\end{array}$ & $\begin{array}{l}\text { Adapta } \\
\text { tion }\end{array}$ & $\begin{array}{l}\text { Resol } \\
\text { ve }\end{array}$ & $\begin{array}{l}\text { Conne } \\
\text { ction }\end{array}$ & $\begin{array}{l}\text { Flexib } \\
\text { ility }\end{array}$ & $\begin{array}{l}\% \\
\text { To } \\
\text { tal }\end{array}$ \\
\hline $\begin{array}{l}\text { 37.a. Competencies } \\
\text { valued by companies } \\
\text { - Hard Sciences } \\
\%\end{array}$ & $\begin{array}{l}0 \\
0\end{array}$ & $\begin{array}{l}0 \\
0\end{array}$ & $\begin{array}{l}1 \\
1\end{array}$ & $\begin{array}{l}0 \\
0\end{array}$ & $\begin{array}{l}0 \\
0\end{array}$ & $\begin{array}{l}0 \\
0\end{array}$ & 1 \\
\hline $\begin{array}{l}\text { 37.b. Competencies } \\
\text { valued by companies } \\
\text { - Soft Sciences } \\
\%\end{array}$ & $\begin{array}{l}0 \\
0\end{array}$ & $\begin{array}{l}0 \\
0\end{array}$ & $\begin{array}{l}4 \\
4\end{array}$ & $\begin{array}{l}0 \\
0\end{array}$ & $\begin{array}{l}0 \\
0\end{array}$ & $\begin{array}{l}2 \\
2\end{array}$ & 7 \\
\hline $\begin{array}{l}\text { 37.c. Competencies } \\
\text { valued by the } \\
\text { university - Hard } \\
\text { Sciences } \\
\%\end{array}$ & $\begin{array}{l}0 \\
0\end{array}$ & $\begin{array}{l}0 \\
0\end{array}$ & $\begin{array}{l}1 \\
1\end{array}$ & $\begin{array}{l}0 \\
0\end{array}$ & $\begin{array}{l}0 \\
0\end{array}$ & $\begin{array}{l}0 \\
0\end{array}$ & 1 \\
\hline $\begin{array}{l}\text { 37.d. Competencies } \\
\text { valued by the } \\
\text { university - Soft } \\
\text { Sciences } \\
\%\end{array}$ & $\begin{array}{l}0 \\
0\end{array}$ & $\begin{array}{l}0 \\
0\end{array}$ & $\begin{array}{l}3 \\
3\end{array}$ & $\begin{array}{l}0 \\
0\end{array}$ & $\begin{array}{l}0 \\
0\end{array}$ & $\begin{array}{l}0 \\
0\end{array}$ & 3 \\
\hline $\begin{array}{l}38.1 \text { World of work } \\
\%\end{array}$ & $\begin{array}{l}0 \\
0 \\
\end{array}$ & $\begin{array}{l}2 \\
2 \\
\end{array}$ & $\begin{array}{l}0 \\
0\end{array}$ & $\begin{array}{l}0 \\
0 \\
\end{array}$ & $\begin{array}{l}0 \\
0\end{array}$ & $\begin{array}{l}0 \\
0 \\
\end{array}$ & 2 \\
\hline $\begin{array}{l}\text { 500.d. Competencies } \\
\text { to be developed in } \\
\text { educators } \\
\%\end{array}$ & $\begin{array}{l}0 \\
0\end{array}$ & $\begin{array}{l}0 \\
0\end{array}$ & $\begin{array}{l}0 \\
0\end{array}$ & $\begin{array}{l}1 \\
1\end{array}$ & $\begin{array}{l}0 \\
0\end{array}$ & $\begin{array}{l}0 \\
0\end{array}$ & 1 \\
\hline $\begin{array}{l}\text { 500.e. Competencies } \\
\text { to be developed in } \\
\text { students } \\
0\end{array}$ & $\begin{array}{l}0 \\
0\end{array}$ & $\begin{array}{l}1 \\
1\end{array}$ & $\begin{array}{l}1 \\
1\end{array}$ & $\begin{array}{l}0 \\
0\end{array}$ & $\begin{array}{l}0 \\
0\end{array}$ & 1 & 3 \\
\hline $\begin{array}{l}\text { Total responses = } \\
100 \%\end{array}$ & 92 & 92 & 92 & 92 & 92 & 92 & \\
\hline
\end{tabular}

\section{Discussion (Research 1 and Research 2)}

These results show the need for developing means and sources of resilience within organizations. Resilience always leads to success for individuals, as well as for the organizations they belong to (Aparicio, 2005, 2007a, 2007b; Rutter, 1985; Werner \& Smith, 1982; Rutter et al, 1991; 1992; Barnard, 1994; de Konink, 2011;Cirulnik, 2001, 2002; Henderson \& Milstein, 2003; Grotberg, 2006; Kokliatenko et al, 1998; Agacisti, 2018; Mo, 2018; Chernyshenko, Kankaraš and Drasgow, 2018; OECD, 2017 a and b;2018 a, b, c and d, among others).

On the one hand, our findings align with those of important researchers. 
On the other hand, the global findings show the significance of other core variables of achievement micro-theories (clear goals, realistic expectations, effort, coping, etc.). All of this refers us to the $\mathrm{N}$-achievement theory (McClelland, 1961); to the Expectancy/Valence theory (Feather \& Davenport, 1981 ); to the Optimistic theory (Seligman, 1991), to Self-Efficacy (Bandura, 1987); to reflective practice and learning organizations (Argirys, 1982; Shon; 1992); to theories related to Coping (Lazarus \& Folfman, 1980) and to Coping Styles and Strategies (Frydenberg \& Lewis, 1996) and its counterpart: Burnout (Freudenberger, 1974).

Finally, in Research 1, the influence of context is made evident. Some Schools generate and consolidate Resilience, while there are others in which this "social competency" is weak: (Dubar, 2000 a, b; Aparicio, 2015 a, b; Silva \& Aparicio, 2015). This situation reveals that the University is in need of professionalization in order to favor the development of competencies beyond disciplinary areas. As regards students, it demands the consolidation of goals, limits and stamina to overcome obstacles, expectations which are presently lacking due to the devaluation of degrees.

\section{Conclusion}

In Research 1, results demonstrate that low levels of Resilience developed both in individuals and in the University (in different Schools) are related to negative Achievement (that is, delayed studies).

In Research 2 (IAM group), on the one hand, there is little awareness of the role of Resilience in the current World of Work, a world which demands strong connections, great flexibility and the ability to adjust. Likewise, respondents value this "psychosocial competency" very little as it relates to Professional and Personal Achievement, despite what has been shown by numerous studies. On the other hand, knowing that resilience is not innate and that it must be "constructed" through interaction with a context (family, university, etc.), the findings show a debt on the part of educational institutions in terms of the formation of social, collective and psychosocial competencies, as they have focused solely on disciplinary learning.

In other words, when it is addressed from the valuation of individuals, Resilience is an undeveloped "absent competency", whereas it is well-developed in the ten countries that lead educational rankings (Aparicio, 2011a; OECD, ops. cit.). This allows us to predict that it will have high impact on levels of achievement, much more so in the post-COVID-19 world.

Faced with this "absence of education" and looking to overcome the emergency generated by COVID-19, we invite universities to act to create new protocols of action, guides of best practice and programs for psychosocial support of different actors (including resilience consolidation programs). Finally, we invite everyone to join together in a RESIL-COVID-19Network. 


\section{References}

[1] Abric, J-C. (2001). Prácticas sociales y representaciones. México: Coyoacán.

[2] Agasisti, T. et al. (2018). "Academic resilience: What schools and countries do to help disadvantaged students succeed in PISA", OECD Education Working Papers, No. 167, OECD Publishing, Paris. http://dx.doi.org/10.1787/e22490ac-en

[3] Alter, N. (1999). La gestion du désordre en entreprise (1st Ed). Paris: L'Harmattan.

[4] Akrich, M., Latour, B., \& Callon, M. (Ed.) (2006). Sociologie de la traduction. París: Minas Paris.

[5] Anthony, E.J. (1987). Risk, Vulnerability, and Resilience. In E.J. Anthony \&, B.J. Cohler (Eds.), The Invulnerable Child (pp. 315-360). New York: The Guildford Press. Cit. par Becoña, op. cit.

[6] Aparicio, M. (1983). La desigualdad de oportunidades. Barcelona: LAIA. Traduction a l'espagnol de l'ouvrage de R. Boudon (1973). L'inégalité des chances. Paris: PUF.

[7] Aparicio, M. (1995). Causas de la deserción en universidades nacionales. Award from the Secretary of University Policy, Argentina.

[8] Aparicio, M. (2005). Les facteurs psychosociaux en relation avec la réussite universitaire et professionnelle. 2e thèse de doctorat. Paris: Université Paris V, Sorbonne. Publié en 2009. Presses de l'Université de Lille3, France.

[9] Aparicio, M. (2007a). Les facteurs psychosociaux à la base de la réussite universitaire et professionnelle : aspects psychologiques et organisationnels. HDR en Psychologie. Lille: Université de Lille3.

[10] Aparicio, M. (2007b). Mobilité et réussite universitaires et professionnelles. Du niveau macro au niveau micro. HDR en Sciences de l'éducation. Paris: Université Paris X, Nanterre.

[11] Aparicio, M. (2009a). La demora en los estudios universitarios. Causas en el plano cuantitativo. Mendoza: ZETA. Vol.1.

[12] Aparicio, M. (2009b). La demora en los estudios universitarios. Causas en el plano cualitativo. Mendoza: ZETA. Vol.2.

[13] Aparicio M. (2011a). Las competencias sociales ¿las grandes ausentes en la formación secundaria y universitaria? Congreso de la Red de Investigación sobre la Calidad de la Educación Superior (RIAICES), Portugal. Du 24 au 26 février.

[14] Aparicio, M. (2011b). Les trajectoires des étudiants, un jeu entre les sujets et leurs contextes institutionnels. In Book of Abstracts 8e Congrès de l'UES (Union Européenne de Systémique (UES), On line, Vol. 1.

[15] Aparicio, M. (2012). Trajectoires universitaires/professionnelles et identité. In J. Clénet (Ed.). Formations et professionnalisations: à l'épreuve de la complexité (195-229).Paris: L’Harmattan. 
[16] Aparicio, M. (2014). University Drop-Outs. A Systemic Play of Subjects, Institutions and Macro Contexts, Journal of Educational and Social Research, $4(2)$.

[17] Aparicio, M. (2015a). Towards a sui generis Systemic Theory: The ThreeDimensional Spiral of Sense. A Study in Argentina Applied to Identity and Professionalization (Part I). Asian Academic Research Journal an Social Science and Humanities, 2(8) 246-282.

[18] Aparicio, M. (2015b). The Theory of the Three-Dimensional Spiral of Sense: An Application with special Reference to Identity and Professionalization in other Disciplinary Areas (Part 2). Asian Academic Research Journal of Social Sciences \& Humanities, 2(8), 194-245.

[19] Aparicio, M. (2016). Professionalization and Identity. A Study in Relation to Achievement at University at the Light of a New Paradigm: The Spiral Three Dimensional of Sens. European Journal of Interdisciplinary Studies, 1(3), 126-131.

[20] Aparicio, M. (2019). Resiliency and Cooperation or Regarding Social and Collective Competencies for University Achievement. An Analysis from a Systemic Perspective. European Journal of Social Sciences Education and Research, 5(3), 123-135.

[21] Aparicio, M. (2020). University Pathways of Graduate Students: Professionalization, Innovation and Identity. A French-Argentine Comparative Study. European Journal of Social Sciences Education and Research, 7(1), 99-112.

[22] Aparicio, M. (2016-2019). PICTO. Agence nationale de science, technologie et innovation, Argentine. Projet dirigé par M. Aparicio, intitulé "Trayectorias laborales, Satisfacción, Profesionalización e Identidad. Un estudio en la UNCuyo en distintos contextos organizacionales (científicos, docentes y administrativos)".

[23] Argyris, C. (1982). Learning and Action: Individual and Organizational. San Francisco: Jossey-Bass. Cit. par Shön, op. cit.

[24] Bandura, A. (1977). Self-Efficacy. Toward an Unifying Theory of Behavioral Change, Psychological Review, 34(2), 191-215.

[25] Barnard, C.P. (1994). Resiliency: A Shift in Our Perception? American Journal of Family Therapy, 22, 135-144.

[26] Becoña, E. (2006). Resiliencia: definición, características y utilidad del concepto. Revista de Psicopatología y Psicología Clínica, 11(3), 125-146.

[27] Coronado Hijón, A. (2017). Alumnado académicamente resiliente. Granada: Editorial GEU.

[28] Cyrulnik, B. (2001). La maravilla del dolor: el sentido de la resiliencia. Barcelona: Granica.

[29] Cyrulnik, B. (2002). Los patitos feos. La resiliencia: una infancia infeliz no determina la vida. Barcelona: Gedisa. 
[30] Dyer, J.G., \& Minton McGuinness, T. (1996). Resilience: Analysis of the Concept. Archives on Psychiatric Nursing, 10(5), 276 - 282.

[31] Dubar, C. (2000 a). La socialisation. Paris: Colin.

[32] Dubar, C. (2000 b). La crise des identités. Paris: PUF.

[33] Chernyshenko, O., M. Kankaraš, \& F. Drasgow (2018). "Social and emotional skills for student success and wellbeing: Conceptual framework for the OECD study on social and emotional skills", OECD Education Working Papers, No. 173, OECD Publishing, Paris.

[34] Feather, N. T., \& Davenport, P. R. (1981). Unemployment and depressive affect: A motivational and attributional analysis. Journal of Personality and Social Psychology, 41(3), 422-436.

Available: https://doi.org/10.1037/0022-3514.41.3.422.

[35] Frydenberg, E., \& Lewis, R. (1996). ACS. Escalas de Afrontamiento para Adolescentes. Madrid: TEA.

[36] Freudenberger, H. (1974). Staff Burn-Out. Journal of Social Issues, 159-165.

[37] Gaglio, G. (2012). Sociologie de l'innovation. Paris: PUF.

[38] Goleman, D. (1996). La inteligencia emocional. Kairós.

[39] Grotberg, E. (2006). La resiliencia en el mundo de hoy. España: Gedisa.

[40] Henderson, N., \& Milstein, M. (2003). Resiliencia en la escuela. Buenos Aires: Paidós.

[41] Koninckx, G. (2011). Dynamics of resiliency in human systems. Proceedings of the 8th Congress of the European Union for Systemics, Bruxels, Belgique. Also in Acta Europeana, $\mathrm{n}^{\circ} 1$.

[42] Kotliarenco, M. A.; Cáceres, D., \& Fontecilla; D. (1997). Estado de Arte en Resiliencia. Organización Panamericana de la Salud.

[43] Lazarus, R. S., \& Folkman, S. (1986). El estrés y procesos cognitivos. Barcelona: Martínez Roca.

[44] Lorenzo, R. (2010). Nuestra capacidad de recuperación ante los obstáculos. Buenos Aires: Andrómeda.

[45] Luthar, S. (Ed.). (2003). Resilience and Vulnerability: Adaptation in the Context of Childhood Adversities. New York: Cambridge University Press.

[46] Manciaux, M. (2003). La resiliencia resistir y rehacerse. Barcelona: Gedisa.

[47] McClelland, D. (1961). The Achieving Society. California University: Van Nostrand.

[48] Masten, A.S., \& Coatsworth, J.D. (1998). Resilience in individual development: The development of competence in favorable and unfavorable environments: Lessons from research on successful children. American Psychologist, 53, 205-220.

[49] Melillo, A., Suárez, E., \& Rodríguez, D. (2004). Resiliencia y subjetividad. Los ciclos de la vida. Buenos Aires: Paidós. Moscovici, S. (1961). La psychanalyse, son image et son public. Paris: PUF. 
[50] Mo, J. (2018). Comment l'enquête PISA mesure-t-elle les compétences de collaboration des élèves?, PISA à la loupe, No. 77, OECD Publishing, Paris. Available : http://dx.doi.org/10.1787/f357f15a-fr.

[51] Novella, A. (2002). Incremento de la resiliencia luego de la aplicación de un programa de psicoterapia breve en madres adolescentes (Tesis de Maestría). Universidad Mayor San Marcos.

[52] OECD (2017a). "Collaborative problem solving", PISA in Focus, No. 78, OECD Publishing, Paris, Available: Available: http://dx.doi.org/10.1787/cdae6d2een

[53] OECD (2017b), "Collaborative schools, collaborative students", in PISA 2015 Results (Vol. V): Collaborative Problem Solving.

[54] OECD (2018 a). Available: http://www.oecd.org/pisa/pisaenespaol.htm/ Consulting May 2, 2018.

[55] OECD (2018b). World Economic Forum "Future of job report". Available: https://www.infobae.com/educacion/2018/01/14/cualesson-los-paísesque-mejor-se-preparan-para-el-trabajo-del-futuro/ Consulting May 22018.

[56] OECD. PISA (2018c). Available: http://www.oecd.org/pisa/pisaenespaol.htm/consultado 2 mai 2018.

[57] OECD (2018d). World Economic Forum "Futur of job report". Available: https://www.infobae.com/educacion/2018/01/14/cuales-sonlos-paises-que-mejor-se-preparan-para-el-trabajo-del-futuro/ Consulting May 2, 2018

[58] Perrenoud, Ph. (2000). La construcción del éxito y del fracaso escolar (3rd ed.). Madrid: Ediciones Morata.

[59] Puerta de Klinkert, M. P. (2002). Resiliencia. La estimulación del niño para enfrentar desafíos. Buenos Aires: Lumen.

[60] Pulgar Suazo, L. (2010). Factores de Resiliencia presentes en Estudiantes de la Universidad del Bío Bío. Tesis de Maestría.

[61] Real Academia de la Lengua (1964). Madrid: Salvat.

[62] Rutter, M. (1985). Resilience in the Face of Adversity: Protective Factors and Resistance to Psychiatric Disorders. British Journal of Psychiatry, 147, 598 611.

[63] Rutter, M. (1992). Resilience: Some Conceptual Considerations. Journal of adolescent Health, 1(14).

[64] Seligman, M. (1991). El optimismo es una ventaja y un placer que se adquiere. Buenos Aires: Atlántida.

[65] Shön, D. (1992). La formación de profesionales reflexivos. Hacia un diseño de la enseñanza-aprendizaje en las profesiones. Madrid: Paidós Ibérica.

[66] Silva, A. M., \& Aparicio, M. (Eds.) (2015). International Handbook about Professional Identities. New York: Academic and Scientific Publishing.

[67] UNESCO (1996). Informe Delors. La educación encierra un tesoro. Paris: UNESCO. 
[68] UNESCO/IESALC (2020). Análisis de impactos, respuestas políticas y recomendaciones. COVID-19. April 6th.

[69] UNESCO/IESALC (2020). Webinaire F. Pedró. El día después del COVID-19. Cómo preparar a las Universidades. June 2, 2020.

[70] Werner, E.E., \& Smith, R.S. (1982). Vulnerable but invincible: A longitudinal study of resilient children and youth. New York: McGraw Hill. 